\title{
ESTIMASI TINGGI BADAN BERDASARKAN UKURAN KEPALA PADA RAS MONGOLOID DI PANDEAN, SURABAYA
}

\author{
Azizatul Haq Larasati ${ }^{1}$, Toetik Koesbardiati ${ }^{2}$, Ahmad Yudianto ${ }^{3}$ \\ ${ }^{1}$ Mahasiswi Magister Ilmu Forensik, Fakultas Pascasarjana, Universitas Airlangga, \\ Surabaya \\ ${ }^{2}$ Jurusan Antropologi, Fakultas Ilmu Sosial dan Ilmu Politik, Universitas Airlangga \\ Surabaya \\ ${ }^{3}$ Jurusan Ilmu Forensik, Fakultas Pascasarjana, Universitas Airlangga Surabaya \\ Email : ${ }^{1}$ azizatullarasati@gmail.com, ${ }^{2}$ tok_unair@yahoo.com, \\ yudi4n6sby@yahoo.co.id
}

\begin{abstract}
Abstrak
Tinggi badan adalah salah satu parameter yang sangat penting dalam identifikasi individu. Tidak setiap kasus forensik ditemukan tulang panjang, sehingga perlu merumuskan bagian tulang kepala untuk mengestimasi tinggi badan. Saat ini belum ada penelitian tentang estimasi tinggi badan berdasarkan ukuran kepala pada ras Mongoloid di Surabaya. Rancangan penelitian ini menggunakan cross sectional analitic. Penelitian dilakukan untuk mengetahui hubungan paling dominan di antara ukuran kepala, termasuk panjang kepala maksimum (g-op), lebar kepala maksimum (eu-eu), lingkar kepala (on-op), lebar mandibula (go-go), dan tinggi morfologi wajah (n-gn) dengan tinggi badan pada laki-laki dan perempuan ras Mongoloid di Pandean, Surabaya.

Besar sampel penelitian ini adalah sebesar total populasi yang memenuhi kriteria, yakni laki-laki usia 25-40 tahun sebanyak 42 orang, dan perempuan 25- 40 tahun sebanyak 45 orang. Pengambilan sampel dilakukan berdasarkan kriteria: Ras Mongoloid, berdiri tegak, bersedia menandatangani informed consent.

Hasil penelitian menunjukkan bahwa kelompok laki-laki variabel tinggi morfologi wajah mempunyai hubungan paling dominan dengan tinggi badan dengan $R^{2}$ sebesar 0,206 dan kelompok perempuan variabel lingkar kepala mempunyai hubungan paling dominan dengan tinggi badan dengan $R^{2}$ sebesar 0,218. Dihasilkan formula regresi estimasi tinggi badan berdasarkan setiap variabel ukuran kepala pada kelompok laki-laki dan kelompok perempuan usia 25-40 tahun ras Mongoloid di Pandean, Surabaya..
\end{abstract}

Kata kunci-estimasi, kepala, tinggi badan

\begin{abstract}
Body height is one of important parameter for an individual identification.. Not every forensic cases could be found long skeleton, so that need formulate another parts of head bone to estimate height. At present there is no research about height estimation based on head size in Mongoloid races in Surabaya. This research design is cross sectional analytic approach. This research purposed to find out the dominant corellation between head size, including maximum head length (g-op), maximum head width (eu-eu), head circumference (on-op), mandibular width (go-go), and high facial morphology (n-gn) with male and female height of Mongoloid race in Pandean, Surabaya.

The sample size of this research is total population which has fulfilled the criteria, 42 people of male aged 25-40 years old, and 45 people of female aged 25-40 years old. The sampling was done based on several criterias, such as: Mongoloid Race, stand tall, willing to signed an informed consent.
\end{abstract}


The result of this study showed that the male group with high facial morphology variable had the most dominant with the stature indicated by $R$ equal to 0,206 and the female group with head circumference variable had the most dominant with the stature indicated by $R$ equal to 0,218. Height estimation formula based on each variable head size was produced by Mongoloid race group of male and female around age 25-40 years old in Pandean, Surabaya.

Keywords—estimation, head, stature 


\section{PENDAHULUAN}

Tinggi badan merupakan salah satu parameter yang sangat penting dalam identifikasi individu (Akhlaghi, et al., 2012; Shrestha et al., 2015). Estimasi tinggi badan juga menjadi salah satu kriteria identifikasi personal yang membantu mempersempit proses penyelidikan di bidang forensik (Pamela, 2013). Menurut Krishan (2008) tulang panjang memiliki tingkat akurasi yang tinggi untuk mengukur estimasi tinggi badan. Namun tidak setiap kasus forensik ditemukan tulang panjang, sehingga perlu merumuskan bagian tulang lain yang dapat digunakan untuk mengukur estimasi tinggi badan yaitu menggunakan tulang dari bagian kepala. Banyak penelitian mengenai estimasi tinggi badan berdasarkan ukuran kepala (Krishan, 2008; Mounika, 2015; Swami, et al., 2015), namun belum pernah ditentukan formula yang tepat dari ukuran panjang maksimal kepala (g-op), lebar maksimal kepala (eueu), lingkar kepala (on-op), lebar mandibula (go-go) atau tinggi morfologi wajah (n-gn).

Krishan (2008), meneliti tentang estimasi tinggi badan berdasarkan variasi pengukuran antropometri chepalo-facial pada kelompok endogami di India Utara. Dalam penelitian tersebut, terdapat 5 variabel pengukuran chepalo-facial, antara lain panjang maksimal kepala (g-op), lebar maksimal kepala (eu-eu), lingkar kepala (on-op), lebar mandibula (go-go), dan tinggi morfologi wajah (n-gn). Hasil penelitian Krishan, (2008) menunjukkan rata-rata tinggi badan laki-laki sebesar $172,31 \mathrm{~cm}$, rata-rata panjang kepala maksimal adalah $17,832 \mathrm{~cm}$, rata-rata lebar kepala maksimal adalah 13,917 cm, rata-rata lingkar kepala sebesar 53,214 cm, rata-rata lebar mandibula sebesar 9,783 $\mathrm{cm}$, dan rata-rata tinggi morfologi wajah sebesar $10,81 \mathrm{~cm}$.
Swami, et al (2015) juga melakukan penelitian mengenai estimasi tinggi badan dari pengukuran antropometrik chepalofacial. Pada 800 orang dari populasi Haryanvi Baniyas yang terdiri dari 400 laki-laki dan 400 perempuan, telah dinyatakan sehat dan tidak memiliki trauma atau cacat tubuh. Pada penelitian Swami, et al., (2005) ini terdapat 3 variabel penelitian, yaitu mengukur lebar mandibula, tinggi morfologi wajah, dan tinggi badan. Dalam penelitiannya, ditemukan bahwa rata-rata tinggi badan laki-laki adalah $168,71 \mathrm{~cm}$ dan perempuan adalah $155,18 \mathrm{~cm}$. Rata-rata tinggi morfologi wajah pada laki-laki adalah $11,07 \mathrm{~cm}$ dan perempuan adalah 10,21 cm. Rata-rata lebar wajah laki-laki adalah $11,45 \mathrm{~cm}$ dan perempuan adalah $10,33 \mathrm{~cm}$. Hasil penelitian Swami, et al., (2015) terlihat bahwa rata-rata ukuran laki-laki lebih besar dibandingkan dengan perempuan.

Adapun penelitian yang dilakukan oleh Mounika, et al. (2015) tentang estimasi tinggi badan berdasarkan lebar wajah di India usia 25-30 tahun, pada 11 sampel laki-laki dan 19 sampel perempuan yang dianalisis menggunakan persamaan rergresi menghasilkan formula untuk estimasi tinggi badan. Hasil penelitiannya diperoleh rentang lebar wajah yaitu 8-12 $\mathrm{cm}$, rata-rata lebar wajah adalah $9,432 \pm 5,72$. Rentang tinggi badan yaitu 150-185 cm, dan rata-rata tinggi badan $161,3 \pm 10,3$. Dapat disimpulkan bahwa terdapat hubungan positif antara lebar mandibula dengan tinggi badan, sehingga ukuran kepala tidak dapat diabaikan dalam kasus forensik untuk estimasi tinggi badan.

Peneliti-peneliti sebelumnya telah merumuskan berbagai formula spesifik estimasi tinggi badan berdasarkan ukuran kepala untuk populasi mereka masingmasing dan menemukan bahwa satu 
formula tinggi badan tidak dapat diaplikasikan pada populasi lain di seluruh dunia (Mounika, 2015).

Penelitian ini, dilakukan pengukuran pada kepala. Kepala adalah salah satu bagian tubuh untuk mengenali identitas individu, tetapi juga tidak mudah dijangkau oleh individu lain karena berkaitan dengan etika. Pada kasus forensik seperti mutilasi sering terpisah antara bagian kepala dengan tubuh individu, sehingga berdasarkan kepala dapat membantu proses identifikasi perkiraan tinggi badan. Estimasi tinggi badan pada tulang panjang sering diteliti dan ditentukan formula regresinya, tetapi belum pernah dilakukan pada kepala bila terjadi kasus tersebut.

Saat ini belum pernah ada penelitian tentang estimasi tinggi badan berdasarkan ukuran kepala pada ras Mongoloid di Surabaya. Hal ini dikarenakan penelitian terkait estimasi tinggi badan berdasarkan ukuran kepala yang meliputi panjang maksimal kepala (g-op), lebar maksimal kepala (eu-eu), lingkar kepala (on-op), lebar mandibula (go-go), dan tinggi morfologi wajah (n-gn), sampai saat ini masih sebatas pada kelompok India Utara (Krishan, 2008).

Penelitian ini dilakukan untuk menganalisis hubungan yang paling dominan di antara ukuran kepala yang meliputi panjang maksimal kepala (g-op), lebar maksimal kepala (eu-eu), lingkar kepala (on-op), lebar mandibula (go-go), dan tinggi morfologi wajah (n-gn) dengan tinggi badan pada kelompok laki-laki dan kelompok perempuan ras Mongoloid di Pandean, Surabaya. Diperoleh formula regresi untuk estimasi tinggi badan bedasarkan ukuran panjang maksimal kepala (g-op), lebar maksimal kepala (eu-eu), lingkar kepala (on-op), lebar mandibula (go-go), dan tinggi morfologi wajah (n-gn) pada kelompok laki-laki dan kelompok perempuan ras Mongoloid di Pandean, Surabaya.

\section{ESTIMASI TINGGI BADAN BERDASARKAN UKURAN KEPALA PADA RAS MONGOLOID}

\subsection{Persebaran Ras Mongoloid di Indonesia}

Lingkungan alam bumi terus mengalami perubahan. Pada jaman pleistosen, bumi mengalami empat kali masa glasial dan tiga kali masa interglasial. Pada zaman glasial, suhu bumi makin dingin sehingga sebagian besar belahan bumi utara dan selatan tertutup oleh lapisan es tebal. Permukaan air laut menurun dan laut yang dangkal ini berubah menjadi daratan (John, 2011). Kondisi demikian memungkinkan bagi manusia ataupun hewan yang hidup pada masa itu melakukan migrasi. Migrasi atau perpindahan individu atau kelompok dari suatu daerah ke daerah lain dilatarbelakangi oleh upaya untuk mempertahankan hidup. Selain didorong untuk mencari daerah yang lebih nyaman dan hangat, perpindahan dilakukan juga untuk mencari daerah-daerah yang masih banyak sumber makanan.

Para ahli geologi memperkirakan bahwa pada jaman pleistosen khususnya ketika terjadinya glasiasi, pulau-pulau di Indonesia ini bersatu dengan daratan Asia (John, 2011). Laut dangkal yang ada di antara pulau-pulau di Indonesia bagian barat surut sehingga membentuk paparan yang disebut dengan Paparan Sunda, yang menyatukan Indonesia bagian barat dengan daratan Asia. Hal yang sama juga terjadi di Indonesia bagian timur. Di daerah ini terbentuk paparan yang kemudian dinamakan Paparan Sahul, yang menyatukan Indonesia bagian timur dengan daratan Australia (John, 2011). Adanya Paparan Sunda memungkinkan terjadinya perpindahan manusia dan hewan dari daratan Asia ke Indonesia bagian barat, atau sebaliknya. Sementara pada Paparan Sahul memungkinkan terjadinya perpindahan manusia dan hewan dari daratan Australia ke Indonesia bagian timur, atau sebaliknya (Jacob, 1967).

Proses migrasi yang terjadi pada masa pleistosen ini menyebabkan wilayah Indonesia mulai dihuni oleh manusia. Persebaran manusia di Indonesia ditandai dengan penemuan fosil manusia purba dan juga alat- 
alat kebudayaan yang digunakan manusia purba untuk bertahan hidup di jamannya. Banyak hipotesis tentang pembagian ras di Indonesia, namun terdapat 2 (dua) teori utama yang didasarkan pada ilmu arkeologi, antropologi budaya, bahasa, paleogeografi, dan zoogeografi, yaitu teori empat tahap dan dua tahap persebaran manusia (Jacob, 1967). Teori pertama, yaitu empat tahap manusia bermigrasi dari Benua Asia ke Indonesia. Migrasi pertama dari populasi Indonesia adalah ras Negroid, kedua Australoid, ketiga Proto-Malay, dan keempat Deutro-Malay. Teori empat tahap migrasi manusia ini diwarnai oleh teori radiasi konsentri von Eicksted, bahwa manusia berasal dari dataran tinggi India, Himalaya atau Tibet dan berkembang menjadi 3 (tiga) ras utama yaitu Negroid, Australoid dan Melanesia (Jacob, 1967).

Teori kedua, yaitu dua tahap manusia bermigrasi yang melibatkan ras Australoid dan Mongoloid. Pertama, ras Australoid yaitu melanesia dan papua. Kedua, ras Mongoloid meliputi Malay yang disebut Deutro-Malay yaitu Malay awal dengan percampuran Mongoloid saat ini. Deutro-Malay berasal dari benua Asia Tenggara. Pada teori ini dijelaskan bahwa ciri-ciri Australoid banyak ditemukan di benua Australia, sedangkan Indonesia bagian barat lebih banyak jenis Malay (Jacob, 1967).

Migrasi atau perpindahan dari berbagai macam ras hingga menghasilkan berbagai macam suku bangsa dan ciri-ciri fisik mendiami wilayah Indonesia. Keanekaragaman tersebut disebabkan oleh perbedaan keadaan alam (letak geografis, iklim), makanan atau nutrisi, dan terjadinya perkawinan. Menurut John (2011) bahwa pada sekitar abad ke-40 sebelum masehi, Pulau Jawa merupakan daerah pertemuan dari beberapa ras dan daerah pertemuan kebudayaan.

Surabaya merupakan salah satu kota besar yang berada di Pulau Jawa. Pulau Jawa termasuk wilayah Indonesia di bagian barat. Jacob (1967) dalam pidato pengukuhan Guru Besar Antropologi Universitas Gajah Mada menyebutkan mengenai variasi ras di Indonesia yang terpola secara kasar. Indonesia barat adalah wilayah dengan pengaruh kuat Mongoloid, sementara Indonesia timur adalah wilayah dengan unsur Austromelonosoid yang kuat. Berdasarkan pendapat dari Jacob (1967) memungkinkan bahwa Surabaya yang berada di Pulau Jawa dan termasuk wilayah Indonesia barat, memiliki pengaruh kuat bahwa penduduk di Surabaya termasuk ras Mongoloid.

Secara garis besar, Surabaya merupakan salah satu kota di Indonesia dengan kepadatan penduduk yang heterogen. Ditinjau dari sejarahnya, Surabaya pada tahun 1743 secara resmi adalah wilayah yang menjadi kekuasaan VOC dan dijadikan pusat kekuasaan di bagian timur Indonesia. Sejak menguasai Surabaya, VOC mulai membuat kebijakan tentang permukiman penduduk yang didasarkan pada perbedaan etnis, yakni Eropa, Tionghoa, dan Melayu. Kelompok etnis Melayu ditinggali oleh etnis Jawa, Madura, Bugis, Lombok, dan Bali (Devi, 2014) yang termasuk dalam ras Deutro-Malay atau Deutro-Melayu, serta merupakan bagian dari ras Mongoloid (Baderi, 2016).

bahwa:

Sebagaimana menurut Baderi, 2016,

"Indonesia adalah negara kepulauan yang terdiri atas beragam suku, bangsa, agama ras dan antargolongan. Berdasarkan ciri-ciri fisik ras Melayu Mongoloid terdiri atas ProtoMelayu (Melayu tua) seperti Batak, Toraja, Dayak, dan Deutro-Melayu (Melayu muda) seperti Bugis, Madura, Jawa, Bali”.

Devi (2014) mengatakan bahwa kelompok etnis Melayu di Surabaya tersebar di Belakan Kidul, Wonokusumo, Belakan Lor, Cantikan, Nyamplungan, Tenggumung, Pandean, Topaten, Batu Putih, Kebon Dalam.

\subsection{Tinggi Badan}

Tinggi badan merupakan pengukuran antropometri kedua setelah berat badan (Soetjiningsih, 1995 dalam Asmiliaty, H., 2012). Tulang dari titik tertinggi di kepala sampai titik terendah di tulang kalkaneus tersusun sebagaimana mestinya untuk membentuk proporsi tinggi badan. Ukuran tinggi badan dapat diperoleh pada saat manusia dalam posisi berdiri tegak tanpa alas 
kaki (Dilon, et al., 2007). Panjang tulang tangan dan kaki kita berbanding secara proporsional dengan tinggi badan, sehingga penentuan tinggi badan bisa dihitung dari panjang tulang panjang dengan rumus regresi (Indriati, E., 2004).

Struktur tubuh masusia disusun atas berbagai macam organ yang tersusun sedemikian rupa, sehingga membentuk tubuh manusia secara utuh, dan kerangka merupakan struktur keras pembentuk tinggi badan. Dalam rangka membangun atau membentuk tinggi badan manusia, maka tubuh dibangun atas struktur susunan tulang-tulang atau kerangka yang terikat atau terkait satu sama lain (Ismurrizal, 2011).

Tulang-tulang panjang terdapat pada rangka tubuh manusia meliputi humerus, radius, ulna, femur, tibia dan fibula. Lengan atas meliputi humerus dan dan lengan bawah terdiri dari radius dan ulna. Ruas tungkai juga dibangun atas tulang-tulang panjang, seperti femur terletak di tungkai atas dan tibia dan fibula di tungkai bawah (Ludwig, 2002).

Tulang batang tubuh termasuk tulang rusuk, tulang belakang, skapula, klavikula, sternum, panggul, dan sakrum. Tulang panggul (tulang pinggul) adalah beberapa tulang yang paling penting untuk analisis antropologis. Panggul terdiri dari tiga bagian, ilium, iskium, dan pubis, masing-masing yang berisi informasi penting untuk penentuan usia kematian atau jenis kelamin pada orang dewasa. Anggota badan termasuk tulangtulang lengan dan kaki (humerus, radius, ulna, femur, tibia, dan fibula). Sebagian besar, tulang lengan tangan dan tungkai kaki disebut tulang panjang karena bentuknya (Bradley, 2007).

\subsection{Estimasi Tinggi Badan}

Estimasi tinggi badan menjadi faktor penting di kasus forensik dalam mengidentifikasi perkiraan tinggi badan individu bila ditemukan potongan tubuh yang tidak lengkap. Bagian tubuh yang pernah diteliti untuk estimasi tinggi badan, yakni ukuran kepala (Shrestha, et al., 2015; Krishan, 2008; Swami, et al., 2015), sternum (Menezes, et al., 2011), lumbar tulang belakang (Klein, et al., 2015), sakrum (Pininski, et al., 2014), ekstermitas atas (Ahmed, 2013a; Akhlaghi, et al., 2012) dan ekstermitas bawah (Ahmed, 2013b).

Dalam penelitian Shrestha, et al., (2015) membahas tentang estimasi tinggi badan berdasarkan ukuran kepala yang diteliti pada 200 sampel di populasi Nepal, menggunakan ukuran panjang maksimal kepala (g-op), lebar maksimal kepala (eu-eu), lebar bigonal (gogo), lebar wajah minimal (ft-ft). Adapun Swami, et al., (2015) meneliti mengenai estimasi tinggi badan menggunakan ukuran tinggi morfologi wajah dan lebar bigonal di populasi Baniyas. Krishan, (2008) juga meneliti tentang estimasi tinggi badan berdasarkan 5 (lima) ukuran kepala di India Utara.

Menezes, et al., (2011) melakukan penelitian mengenai estimasi tinggi badan yang diukur dari lebar sternum pada 40 sampel sternum perempuan yang diotopsi di perguruan tinggi Kasturba di India Selatan. Penelitian tentang estimasi tinggi badan juga dilakukan oleh Giurazza, et al. (2013) berdasarkan ukuran skapula menggunakan metode CT Scan di populasi Italia. Selanjutnya, Klein, et al., (2015) juga melakukan penelitian di Jerman tentang estimasi tinggi badan menggunakan ukuran lumbar tulang belakang. Penelitian tentang estimasi tinggi badan dari ukuran sakrum juga diteliti oleh Pininski, et al., (2014) pada 210 sampel yang didapatkan dari koleksi rangka manusia di Universitas Witwatersrand, Johanesburg, Afrika Selatan. Pelin, et al., (2005), juga meneliti tentang estimasi tinggi badan berdasarkan ukuran sakrum. Penelitian yang sama, estimasi tinggi badan berdasarkan ukuran sakrum dilakukan pada 126 sampel, yang terdiri dari 110 laki-laki dan 106 perempuan di Jepang (Torimitsu, et al., 2014).

Ekstermitas atas atau anggota gerak atas terdiri dari beberapa macam tulang yang dikaitkan dengan kerangka badan. Tulangtulang yang membentuk kerangka lengan dan tangan antara lain: gelang bahu yang terdiri dari skapula dan klavikula, humerus, ulna dan radius, karpal, metakarpal, dan phalangs. Akhlaghi, et al., (2012) meneliti tentang estimasi tinggi badan berdasarkan ektermitas 
atas dari ukuran panjang lengan atas, panjang lengan bawah, panjang lengan total, panjang tangan, lebar tangan, panjang jari kedua, panjang jari ketiga, panjang jari keempat, dan panjang jari kelima pada 100 sampel yang terdiri dari 50 laki-laki dan 50 perempuan di Iran. Penelitian yang dilakukan oleh Ahmed, (2013a) tentang estimasi tinggi badan berdasarkan ektermitas atas menggunakan ukuran panjang lengan atas, panjang ulna, lebar tangan dan panjang tangan pada 200 sampel yang terdiri dari 100 laki-laki dan 100 perempuan di Sudan.

Ektermitas bawah atau anggota gerak bawah terdiri dari beberapa macam tulang yang membentuk kerangka tungkai dan kaki antara lain: pelvis, femur, tibia dan fibula, tarsal, metatarsal, dan phalangs. Bagian ukuran panjang dari tulang pada ekstermitas bawah dapat digunakan untuk menentukan estimasi tinggi badan. Ilayperuma, et al. (2010), meneliti tentang estimasi tinggi badan menggunakan ukuran panjang ulna pada 258 sampel yang terdiri dari 140 laki-laki dan 118 perempuan di Sri Lanka. Sutriani (2013) juga melakukan penelitian mengenai perbedaan tinggi badan berdasarkan panjang ulna dengan tinggi badan aktual di Semarang. Penelitian yang dilakukan oleh Ahmed (2013b) tentang estimasi tinggi badan ditentukan dari ukuran panjang tibia, panjang kaki, dan lebar kaki pada 160 sampel, yang terdiri dari 80 laki-laki dan 80 perempuan di Sudan, Arab. Panjang telapak kaki juga dapat digunakan untuk menentukan estimasi tinggi badan pada ras Mongoloid di Indonesia (Wilianto, et al., 2010).

Berdasarkan uraian di atas, bahwa estimasi tinggi badan dapat ditentukan dari berbagai ukuran panjang dan lebar tulang pada tubuh. Penelitian ini, hanya memfokuskan 5 (lima) ukuran kepala, yakni panjang maksimal kepala (g-op), lebar maksimal kepala (eu-eu), lingkar kepala (on-op), lebar bigonal (go-go), dan tinggi morfologi wajah (n-gn) untuk estimasi tinggi badan.

\subsection{Ukuran Dimensi Kepala}

Ukuran dimensi kepala adalah ukuran yang mencakup panjang, lebar, dan tinggi pada kepala. Berdasarkan literatur dari penelitian sebelumnya, ukuran kepala yang sering diukur untuk estimasi tinggi badan antara lain panjang maksimal kepala (g-op) (Krishan, 2008; Shrestha, et al., 2015), lebar maksimal kepala (eu-eu) (Krishan, 2008), lingkar kepala (g-op-g) (Krishan, 2008), lebar bigonal (go-go) (Krishan, 2008; Swami, et al., 2015), tinggi morfologi wajah (n-gn) (Krishan, 2008; Swami, et al., 2015), lebar wajah (zyzy) (Mounika, et al., 2015), dan lebar minimal frontal (ft-ft) (Shrestha, et al., 2015).

Ukuran kepala yang pernah diteliti untuk estimasi tinggi badan, pertama menurut Shrestha, et al., (2015) meneliti ukuran panjang maksimal kepala (g-op) digunakan untuk mengestimasi tinggi badan pada lakilaki dan perempuan. Berdasarkan hasil penelitian Shrestha, et al., (2015) bahwa terdapat hubungan positif antara ukuran panjang maksimal kepala (g-op) dengan tinggi badan pada laki-laki sebesar 0,327 (p-value < $0,05)$, sedangkan pada perempuan sebesar 0,383 (p-value < 0,05). Adapun, Krishan (2008) juga meneliti estimasi tinggi badan berdasarkan ukuran panjang maksimal kepala (g-op) di India Utara. Berdasarkan hasil penelitian Krishan (2008) bahwa terdapat hubungan positif antara ukuran panjang maksimal kepala (g-op) dengan tinggi badan sebesar $\mathrm{r}=0,775$ dan $\mathrm{p}=0,063$ ( $\mathrm{p}$-value < 0,001). Pada penelitian Shrestha, et al., (2015) dan Krishan (2008) bahwa terdapat hubungan positif antara panjang maksimal kepala (g-op) dengan tinggi badan, sehingga ukuran tersebut dapat digunakan untuk estimasi tinggi badan.

Menurut Krishan (2008) terdapat hubungan positif antara lebar maksimal kepala (eu-eu) dengan tinggi badan sebesar $\mathrm{r}=0,682$ dan $\mathrm{p}=0,061(\mathrm{p}$-value $<0,001)$, sehingga ukuran tersebut dapat digunakan untuk mengestimasi tinggi badan.

Krishan (2008) menggunakan ukuran lingkar kepala (on-op) untuk mengestimasi tinggi badan. Menurut Krishan (2008) bahwa terdapat hubungan positif antara lingkar kepala dengan tinggi badan sebesar $\mathrm{r}=0,781$ dan $\mathrm{p}=0,059$ ( $\mathrm{p}$-value $<0,001)$. Sehingga, ukuran dari lingkar kepala (on-op) dapat digunakan untuk mengestimasi tinggi badan. 
Menurut Swami, et al., (2015) bahwa ukuran lebar bigonal (go-go) memiliki hubungan positif dengan tinggi badan laki-laki dan perempuan yakni sebesar $r=0,164$ dan $p$ $=0,0009$ (p-value $<0,01)$ pada laki-laki dan $\mathrm{r}$ $=0,119$ dan $\mathrm{p}=0,016(\mathrm{p}$-value < 0,01) pada perempuan. Adapun Krishan (2008) menggunakan ukuran lebar bigonal (-go-go) untuk estimasi tinggi badan. Di mana, ada hubungan positif antara lebar bigonal (go-go) dengan tinggi badan sebesar $\mathrm{r}=0,462$ dan $\mathrm{p}=$ 0,081 (p-value < 0,001). Berdasarkan penelitian Swami, et al., (2015) dan Krishan (2008) bahwa terdapat hubungan yang signifikan antara lebar bigonal (go-go) dengan tinggi badan, sehingga ukuran tersebut dapat digunakan untuk mengestimasi tinggi badan.

Estimasi tinggi badan berdasarkan ukuran lebar wajah (zy-zy) diteliti oleh Mounika, et al., (2015). Di dalam penelitian Mounika, et al., (2015) tersebut menghasilkan persamaan regresi untuk mengestimasi tinggi badan dari lebar wajah (zy-zy), dan tidak mendapatkan hubungan positif antara tinggi badan dengan lebar wajah. Sehingga, ukuran lebar wajah (zy-zy) tidak diukur dalam penelitian ini.

Swami, et al., (2015) menggunakan ukuran tinggi morfologi wajah (n-gn) untuk mengestimasi tinggi badan. Dalam penelitian Swami, et al., (2015) bahwa terdapat hubungan positif antara tinggi morfologi wajah (n-gn) dengan tinggi badan laki-laki dan perempuan. Pada laki-laki sebesar $\mathrm{r}=0,177$ dan $\mathrm{p}=0,0003$ ( $\mathrm{p}$-value $<0,01)$ dan pada perempuan sebesar $r=0,150$ dan $p=1,002(p-$ value < 0,01). Adapun dalam penelitian Krishan (2008) bahwa terdapat hubungan positif antara tinggi morfologi wajah (n-gn) dengan tinggi badan pada sampel yang digunakan laki-laki sebesar 0,455 (p-value < 0,001). Berdasarkan penelitian Swami, et al., (2015) dan Krishan (2008) terdapat hubungan positif antara tinggi morfologi wajah (n-gn) dengan tinggi badan, oleh karena itu ukuran tersebut dapat digunakan untuk mengestimasi tinggi badan.

Penelitian Shrestha, et al., (2015) yakni menganalisis ukuran lebar minimal frontal (ftft) untuk estimasi tinggi badan. Berdasarkan penelitian Shrestha, et al., (2015) bahwa korelasi antara lebar minimal frontal dengan tinggi badan pada laki-laki sebesar $r=0,271$ dan $\mathrm{p}=0,100$ ( $\mathrm{p}$-value $<0,05)$, sedangkan perempuan sebesar $r=0,036$ dan $p=0,800$ ( $p$ value $<0,05)$. Nilai $p_{\text {laki-laki }}=0,100>0,05$ dan $p_{\text {perempuan }}=0,800>0,05$ menunjukkan bahwa tidak ada hubungan positif antara lebar minimal frontol (ft-ft) dengan tinggi badan, sehingga ukuran tersebut tidak diteliti dalam penelitian ini.

Pada penelitian di atas, telah diuraikan bahwa terdapat hubungan signifikan dan tidak signifikan antara ukuran kepala dengan tinggi badan, serta nilai korelasi yang berbeda berdasarkan populasi yang berbeda. Berdasarkan uraian di atas, penelitian ini akan mencari hubungan signifikan untuk mengukur estimasi tinggi badan berdasarkan ukuran kepala yang meliputi panjang maksimal kepala (g-op), lebar maksimal kepala (eu-eu), lingkar kepala (on-op), lebar mandibula (go-go), dan tinggi morfologi wajah (n-gn).

\section{METODE PENELITIAN}

Penelitian ini merupakan penelitian cross sectional analytic. Penelitian cross sectional analitic yaitu rancangan penelitian dengan melakukan pengukuran atau pengamatan variabel independen dan varibel dependen secara bersamaan atau sekali waktu. Lokasi penelitian ini dilakukan di Kampung Pandean, Kelurahan Peneleh, Surabaya. Besar sampel penelitian ini adalah sebanyak total populasi yang memenuhi kriteria, yakni pada laki-laki usia 25-40 tahun sebanyak 42 sampel laki-laki dan perempuan 25-40 tahun sebanyak 45 sampel perempuan. Adapun kriteria penelitian sebagai berikut: Ras Mongoloid, dapat berdiri dengan tegak, bersedia menandatangani lembar persetujuan/ informed consent.

Pengumpulan data dilakukan dengan menentukan subyek penelitian laki-laki dan perempuan usia 25-40 tahun berdasarkan kriteria yang telah ditentukan peneliti, memberikan informasi pengambilan data penelitian kepada sampel penelitian, pengisian informed consent yang berisi bahwa sampel penelitian bersedia diambil data penelitian oleh peneliti. Setelah dilakukan pengumpulan data, selanjutnya subyek penelitian laki-laki dan perempuan usia 25-40 tahun melakukan 
pengukuran yang diperlukan dalam penelitian ini, yaitu ukuran kepala yang meliputi panjang maksimal kepala (g-op), lebar maksimal kepala (eu-eu), lingkar kepala (on-op), lebar mandibula (go-go), tinggi morfologi wajah (ngn) dan tinggi badan. Hasil pengukuran ditulis pada lembar form isian yang telah berisi data subyek penelitian.

Pengukuran panjang kepala maksimal dimulai dari glabella (g) ke occiput yang mempunyai hasil baca atau skala paling besar, alat yang digunakan kaliper lengkung. Ukuran lebar kepala maksimal didapat dari tulang parietal yang menonjol hingga mendapatkan angka maksimal, menggunakan kaliper lengkung. Mengukur lingkar kepala dilakukan dengan menggunakan meteran antropometri yang diambil dari garis tengah dahi tepat di atas superior orbital melalui occiput (opistokranion). Pengukuran lebar mandibula dilakukan dengan menggunakan kaliper lengkung yang diambil dari masing-masing sudut posterior ramus mandibula dan inferior mandibular corpus. Pengukuran tinggi morfologi wajah diambil menggunakan kaliper geser mulai dari titik gnathion (terletak di bahwa dagu) sampai titik nasion. Hasil pengukuran yang diperoleh dalam skala milimeter (mm).

Instrumen yang digunakan untuk pengambilan data penelitian ini meliputi, kaliper lengkung (spreading caliper), kaliper geser (sliding caliper), pita meteran plastik untuk mengukur bagian kepala, dan meteran baja dan penggaris untuk mengukur tinggi badan. Kaliper lengkung (spreading caliper) yaitu instrumen antropometri terdiri dari dua batang melengkung yang mana pada lengkung sisi kiri di titik tengahnya terdapat skala yang terhubungan dengan lengkung sisi kanan. Kaliper lengkung ini digunakan untuk mengukur kepala pada subyek hidup maupun benda mati. Terdapat dua model kaliper lengkung, yaitu kaliper lengkung kecil digunakan untuk ukuran hingga $30 \mathrm{~cm}(300$ $\mathrm{mm}$ ), dan kaliper lengkung besar untuk ukuran hingga $60 \mathrm{~cm}(600 \mathrm{~mm})$ digunakan untuk mengukur anggota tubuh atau tulang panjang (Kolar, JC, Elizabeth, MS, 1996). Kaliper geser (sliding caliper), terdiri dari dua bagian dasar, skalametri dengan batang tegak lurus, di mana ujung batang tegak lurus dan batang yang lain dapat digeser. Kedua batang terdapat dua ujung, yakni satu sisi lancip dan sisi lainnya tumpul. Pada subjek hidup, menggunakan ujung yang tumpul agar lebih aman. Ujung yag lancip digunakan untuk mengukur tulang. Kaliper geser ini mempunyai skala ukur hingga $20 \mathrm{~cm}$ (200 $\mathrm{mm}$ ) (Kolar, JC, Elizabeth, MS, 1996).

Pengukuran tinggi badan diukur dari titik tertinggi di kepala yang disebut vertex, ke titik terendah dari tulang kalkaneus (the calcanear tuberosity) yang disebut heel. Alat yang digunakan peneliti untuk mengukur tinggi badan adalah meteran baja dan penggaris untuk menunjukkan tinggi badan subyek penelitian yang tepat. Hasil pengukuran dalam skala sentimeter $(\mathrm{cm})$.

Analisis data dimulai dengan analisis deskriptif untuk mendeskripsikan karakteristik subjek penelitian. Kemudian, dilakukan beberapa pengujian data untuk dapat membuktikan data yang digunakan atau didapatkan telah menggambarkan secara tepat konsep yang akan diukur, diantaranya adalah uji normalitas data Kolmogorov Smirnov (apabila nilai sig. > 0,05 maka data berdistribusi normal), uji multikolenearitas (jika nilai VIF (Variance Inflation Factor) < 10, maka hal ini berarti dalam persamaan regresi tidak ditemukan adanya korelasi antar variabel bebas atau bebas multikolinieritas), uji autokorelasi (jika nilai Durbin Watson antara 1,55 s.d 2,46 maka tidak terjadi autokorelasi) dan uji heteroskedastisitas (bila sig. $\alpha>5 \%$ maka tidak terjadi heteroskedastisitas). Apabila data penelitian memenuhi asumsi atau syarat tersebut di atas, maka data penelitian dapat dianalisis menggunakan regresi linier. Persamaan regresi linier dapat dirumuskan sebagai berikut (Sugiyono, 2008):

$y=a+b x$

Keterangan:

$y$ : nilai yang diprediksikan, yaitu estimasi tinggi badan

$a$ : konstanta atau bila harga $\mathrm{X}=0$

$b:$ koefisien regresi 
$x$ : nilai variabel independen, yaitu masingmasing ukuran kepala

Di mana nilai $a$ dan $b$ dicari terlebih dahulu dengan menggunakan persamaan berikut (Sugiyono, 2008):

$$
\begin{aligned}
& a=\frac{\left(\sum x\right)^{2}\left(\sum y\right)-\left(\sum x\right)\left(\sum x y\right)}{n\left\llcorner x^{2}-(\angle x)^{2}\right.} \\
& b=\frac{n \sum x y-\left(\sum x\right)\left(\sum x\right)}{n \sum x^{2}-\left(\sum x\right)^{2}}
\end{aligned}
$$

Keterangan:

$$
\begin{array}{ll}
\mathrm{n} & \text { : jumlah sampel } \\
\Sigma \mathrm{x} & \text { : total tinggi badan sampel } \\
\Sigma \mathrm{y} & \text { : total salah satu ukuran kepala yang } \\
& \text { ingin dihitung }
\end{array}
$$

\section{HASIL DAN PEMBAHASAN}

Setelah dilakukan pengambilan data, selanjutnya diperoleh sebaran hasil penelitian yang meliputi variabel tinggi badan, panjang kepala maksimal (g-op), lebar kepala maksimal (eu-eu), lingkar kepala (on-op), lebar mandibula (go-go), tinggi morfologi wajah (n-gn) pada kelompok laki-laki dan kelompok perempuan, dapat dilihat dalam tabel berikut ini:

Tabel 1.1 Analisis deskriptif variabel tinggi badan dan ukuran kepala yang meliputi panjang kepala maksimal (g-op), lebar kepala maksimal (eu-eu), lingkar kepala (on-op), lebar mandibula (go-go), dan tinggi morfologi wajah (n-gn) pada kelompok laki-laki dan perempuan.

\begin{tabular}{lccccc}
\hline \multirow{2}{*}{ Var. } & \multicolumn{2}{c}{ Laki-laki } & & \multicolumn{2}{c}{ Perempuan } \\
\cline { 2 - 3 } \cline { 5 - 6 } & Mean & SD & & Mean & SD \\
\hline FBIK & 1987.86 & 78.399 & & $1533: 36$ & 61.283 \\
LMK & 157.6 & 5.19 & & 148.5 & 8.26 \\
LK & 564.9 & 14.88 & 541.6 & 14.27 \\
LM & 107.3 & 7.09 & 101.2 & 5.05 \\
\hline
\end{tabular}

Ketrangan:

Var. : Variabel

SD : Standar deviasi

TB : Tinggi badan

PMK : Panjang kepala maksimal

LMK : Lebar kepala maksimal

LK : Lingkar kepala

LM : Lebar mandibula

MW : Tinggi morfologi wajah

Berdasarkan hasil analsis deksriptif di tabel 1.1 dapat dilihat bahwa ukuran tinggi badan dan ukuran kepala yang meliputi panjang kepala maksimal (g-op), lebar kepala maksimal (eu-eu), lingkar kepala (on-op), lebar mandibula (go-go) dan tinggi morfologi wajah (n-gn) laki-laki lebih besar bila dibandingkan dengan perempuan sedikit mempunyai ukuran lebih kecil.

Setelah diperoleh data penelitian, kemudian data dianalisis menggunakan regresi linier yang ditunjukkan pada tabel berikut ini:

Tabel 1.2 Analisis regresi variabel tinggi badan dan ukuran kepala yang meliputi panjang kepala maksimal (g-op), lebar kepala maksimal (eu-eu), lingkar

\begin{tabular}{|c|c|c|c|c|c|c|}
\hline \multirow[b]{2}{*}{ Model } & \multicolumn{3}{|c|}{ Laki-laki } & \multicolumn{3}{|c|}{ Perempuan } \\
\hline & Constant & Koef & $\mathrm{R}^{2}$ & Constant & Koef & $\mathrm{R}^{2}$ \\
\hline PMK & 1322 & 1,745 & 0,027 & 1029 & 2,912 & 0,063 \\
\hline LMK & 1 & 3,488 & 0,0 & 13 & 1,090 & 0,021 \\
\hline LK & & & & & 2 , & \\
\hline LM & 1154,652 & 4,588 & 0,170 & 998,957 & 5,277 & 0,189 \\
\hline MW & 984,285 & 5,315 & 0,206 & 1242,773 & 2,449 & 0,070 \\
\hline
\end{tabular}
kepala (on-op), lebar mandibula (go-go), dan tinggi morfologi wajah (n-gn) pada kelompok laki-laki dan perempuan.

Keterangan:

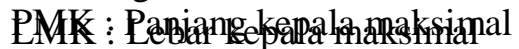

LK : Lingkar kepala

LM : Lebar mandibula

MW : Tinggi morfologi wajah 
Pada tabel 1.2 dapat dilihat hubungan paling tinggi hingga paling rendah antara tinggi badan dengan masing-masing variabel ukuran kepala sebagai berikut, pada kelompok laki-laki yakni tinggi morfologi wajah $\mathrm{R}^{2}$ sebesar 0,206, lebar mandibula $\mathrm{R}^{2}$ sebesar 0,170 , lingkar kepala $\mathrm{R}^{2}$ sebesar 0,072, lebar kepala maksimal $\mathrm{R}^{2}$ sebesar 0,052, dan panjang kepala maksimal $\mathrm{R}^{2}$ sebesar 0,027 . Pada kelompok perempuan yakni lingkar kepala $\mathrm{R}^{2}$ sebesar 0,218 , lebar mandibula $\mathrm{R}^{2}$ sebesar 0,189, tinggi morfologi wajah $\mathrm{R}^{2}$ sebesar 0,070, panjang kepala maksimal $\mathrm{R}^{2}$ sebesar 0,063 , dan lebar kepala maksimal $\mathrm{R}^{2}$ sebesar 0,021 .

Didapatkan formula regresi estimasi tinggi badan berdasarkan ukuran kepala sebagai berikut:

Formula estimasi tinggi badan pada lakilaki

a. Berdasarkan ukuran panjang kepala maksimal (g-op)

$1322,745+1,745 \times$ (panjang

kepala maksimal)

b. Berdasarkan ukuran lebar kepala maksimal (eu-eu)

1097,263+3,488x(lebar kepala maksimal)

c. Berdasarkan ukuran lingkar kepala (onop)

$843,130+1,423 x$ (lingkar kepala)

d. Berdasarkan ukuran lebar mandibula (gogo)

$1154,652+4,588 \times$ (lebar mandibula)

e. Berdasarkan ukuran tinggi morfologi wajah (n-gn)

$984,285+5,315 x$ (tinggi morfologi wajah)

\section{Formula estimasi tinggi badan pada perempuan}

a. Berdasarkan ukuran panjang kepala maksimal (g-op)

$1029,127+2,912 x$ (panjang kepala maksimal)

b. Berdasarkan ukuran lebar kepala maksimal (eu-eu)

1371,464+1,090x(lebar kepala maksimal)

c. Berdasarkan ukuran lingkar kepala (onop) 444,431+2,011x(lingkar kepala)

d. Berdasarkan ukuran lebar mandibula (gogo)
$998,957+5,277 x($ lebar mandibula)

e. Berdasarkan ukuran tinggi morfologi wajah (n-gn

$1242,773+2,449 x$ (tinggi morfologi wajah)

\section{KESIMPULAN DAN SARAN}

Ukuran tinggi morfologi wajah mempunyai hubungan paling dominan dengan tinggi badan pada kelompok laki-laki ras Mongoloid di Pandean, Surabaya. Variabel ukuran lingkar kepala mempunyai hubungan paling dominan dengan tinggi badan pada kelompok perempuan ras Mongoloid di Pandean, Surabaya. Diperoleh formula regresi estimasi tinggi badan berdasarkan masingmasing variabel ukuran kepala, antara lain panjang maksimal kepala (g-op), lebar maksimal kepala (eu-eu), lingkar kepala (onop), lebar mandibula (go-go), dan tinggi morfologi wajah (n-gn) pada kelompok lakilaki dan kelompok perempuan ras Mongoloid di Pandean, Surabaya.

Formula regresi yang dihasilkan dalam penelitian ini dapat digunakan untuk estimasi tinggi badan seseorang atau individu apabila hanya ditemukan atau diketahui salah satu variabel ukuran kepala, khususnya pada manusia ras Mongoloid laki-laki dan perempuan usia 25-40 tahun di Pandean, Surabaya. Oleh karena itu, perlu dilakukan penelitian pada populasi yang lebih luas bila ingin mendapatkan formula regresi yang bisa digunakan untuk populasi Surabaya.

\section{DAFTAR PUSTAKA}

Ahmed A.A. 2013a. "Estimation of Stature from the Upper Limb Measurements of Sudanese Adults." Forensic Science International, (228) 178.e1178.e7

Ahmed A.A. 2013b. "Estimation of Stature using Lower Limb Measurements in Sudanese Arabs." Journal of Forensic and Legal Medicine, (20) 483-488

Akhlaghi M., Marzieh H, Behzad M., 2012. "Estimation of Stature from 
Upper Limb Anthropometry in Iranian Population." Journal of Forensic and Legal Medicine, (19) 280-284

Asmiliaty H. 2012. Model Prediksi Tinggi Badan untuk Kelompok Usia Dewasa Muda dengan Menggunakan Prediktor Panjang Depa di Fakultas Kesehatan Masyarakat Universitas Indonesia tahun 2012. Jakarta: Universitas Indonesia.

Baderi F. 2016. Menempatkan SARA Secara Bijak. Retrieved from http://www.neraca.co.id/article/75808/m enempatkan-sara-secara-bijak, on 3rd November 2017.

Bradley A. J. 2007. Forensic Anthropology. New York: Chelsea House an Imprint of Infobase Publishing.

Devi S. 2014. Etnis Tionghoa dalam Sejarah Pendidikan Masyarakat Kota Surabaya. Surabaya: Revka Petra Media.

Dilon, Fahmida U. 2007. Handbook Nutritional Assessment. Jakarta: SEAMEO Universitas Indonesia.

Giurazza F, Riccardo D.V, Emilano S, Roberto L.C, Francesco D.A, Rosario F.G, Sergio S, Bruno B.Z., 2013. "Stature Estimation from Scapular Measurements by CT Scan Avaluation in an Italian Population." Legal Medicine, (15) 202-208

Ilayperuma I, Nanayakkara G, Palahepetiya, 2010. "A Model for the Estimation of Personal Stature from the Length of Forearm." International Journal Morphology, 28(4) 1081-1086

Indriati E. 2004. Antropologi Forensik. Yogyakarta: Gajah Mada University Press.

Ismurrizal, 2011. Penentuan Tinggi Badan Berdasarkan Panjang Telapak Tangan. Tesis. Medan: Universitas Sumatera Utara.
Jacob T. 1967. The Racial History of The Indonesian Region. Drukkerij Neerlandia: Utrech.

John, A. 2011. "Analisis Penyebab Konflik Papua dan Solusinya secara Hukum Internasional." WPLO, 79-83.

Klein A, Katrin N, Julian GS, Chanasorn $\mathrm{P}$, Klaus P, Michael MM, dan Gerd H, 2015. "On the Relationship between Stature and Anthropometric Measurements of Lumbar Vertebrae." Science and Justice, (5) 17-20

Kolar, JC, Elizabeth MS, 1996. Craniofacial Anthropometry Practicial Measurement of the Head and Face for Clinical, Surgical and Research Use. Charles C. Thomas Publisher LTD. United State America.

Krishan K. 2008. "Estimation of Stature from Cephalo-facial Anthropometry in North Indian Population." Forensic Science International, (181) 52e1-52e6

Ludwig J. 2002. Skeletal System. In: Handbook of Autopsy Practice. $3^{\text {rd }}$ ed. New Jersey: Humana Press.

Menezes RG, KRN, Francis NP, Monteiro G, Pradeep K, Tanuj K, Selma U, PP Jagadish R, Prateek R, Stany WL, Sneha GK, 2011. "Estimation of Stature from the Length of the Sternum In South Indian Females." Journal of Forensic and Legal Medicine, (18) 242-245

Mounika SKYB., 2015. "Estimation of Stature from the Facial Width." Journal Pharmaceutical Science and Research, (7) 353-354

Pamela M, Misiani M, Ogeng'o J, Obimbo M, Gikenye G., 2013. "Estimation of the Length of the Tibia from Dimensions of the Distal Articular Surfaces of the Tibia in Adult Kenyans." International Journal of Healthcare and Biomedical Research, Vol. 1, Issue. 4, pp. 250-257.

Pininski M, Desire' B., 2014. "Estimating Stature in South African Populations Using Various Measures of the 
Sacrum." Forensic Science

International, (234) 182.e1- 182.e7

Shrestha R, Pramod KS, Harihar W, Tulsi K, Tanuj K, Kewal K. 2015. "Craniometric Analysis for Estimation of Stature in Nepalese Population - A Study on an Autopsy Sample." Journal Forensic Science International, (248) 187.e1-187.6.

Sutriani, K.T. 2013. Perbedaan Antara Tinggi Badan Berdasarkan Panjang Ulna Dengan Tinggi Badan Aktual Dewasa Muda Di Kota Semarang. Semarang: Universitas Diponegoro.

Swami S, Kumar M, Patnaik VVG., 2015. "Estimation of Stature from Facial Anthropometric Measurements In 800 Adult Haryanvi Baniyas." International Journal of Basic and Applied Medical Sciences, (5) 122-132

Torimitsu S, Yohsuke M, Hisako S, Namiko I, Mutsumi H, Daisuke Y, Go I, Ayumi M, Fumiko C, Hirotaro I., 2014. "Stature Estimation in Japanese Cadavers Using the Sacral and Coccygeal Length Measured with Multidetector Computed Tomography." Legal Medicine, (16) 14-19

Wilianto W, Agus M.A., 2010. Perkiraan Tinggi Badan Berdasar Panjang Telapak Kaki pada Populasi Mongoloid Dewasa di Indonesia. Majalah Kedokteran Forensik Indonesia, (12) 4 